\title{
ПОЛИТИЧЕСКИЙ ИСЛАМ И СОВРЕМЕННЫЕ ПРОБЛЕМЫ ГЛОБАЛЬНОГО УПРАВЛЕНИЯ
}

\author{
М. Г. Маргарян \\ Академия государственного управления Республики Армения, г. Ереван, Республика Армения
}

Информация о статье

Дата поступления

25 января 2018 г.

Дата принятия к печати

21 мая 2018 г.

Дата онлайн-размещения

8 июня 2018 г.

\section{Ключевые слова}

Глобальное управление; политический ислам; Большой

Ближний Восток; права

человека; демократия;

сотрудничество цивилизаций

\begin{abstract}
Аннотация
Современные тенденции глобальной неопределенности требуют переосмысления формы и векторов развития глобального управления. В данном контексте в статье комплексно исследуются проблемы развития политического ислама как одного из фракторов, влияющих на формирование процесса глобального управления. Автор убежден, что современные тенденции демонизации политического ислама превратили его в субъекта столкновения цивилизаций. С этой точки зрения предлагается переосмыслить политику модернизации как глобального управления, так и политического ислама с целью их демократизации - отказаться от реализации концепции столкновения цивилизаций и развивать концепцию сотрудничества цивилизаций.
\end{abstract}

\section{POLITICAL ISLAM AND THE MODERN ISSUES OF GLOBAL GOVERNANCE}

\author{
Mamikon G. Margaryan \\ Public Administration Academy of the Republic of Armenia, Yerevan, Republic of Armenia
}

\section{Article info}

Received

January 25, 2018

Accepted

May 21, 2018

Available online

June 8, 2018

\section{Keywords}

Global Governance; Political Islam; the Greater Middle East; human rights; democracy; cooperation of civilizations

\begin{abstract}
Modern tendencies of global uncertainties raise the imperative of rethinking of forms and directions of development of global governance. In this context the article comprehensively researches the issues of development of political Islam as one of the factors, which form the current stage of global governance. The author is convinced that modern tendencies of «demonization" of political Islam transformed it into a subject of «clash of civilizations». From this perspective the article suggests rethinking the modernization policy of both global governance and political Islam to democratize them and refuse from implementation of the concept of «clash of civilization» and develop the concept of «cooperation of civilizations».
\end{abstract}

Введение: ислам в меняющемся мире

XXI век войдет в историю событиями глобального масштаба, в частности нарушением баланса сил, установившегося после завершения холодной войны, и продолжающимся его поиском на мировой арене. Процесс глобализации фактически бросил человечеству уникальный в своем роде вызов, для ответа на который необходимо объяснить многоуровневые противоречивые изменения, происходящие в процессе трансорормации ценностных контуров глобального управления. Противоречия отмечаются, с одной стороны, между особенностями процессов глобализации и самоидентификации, а с другой - между уровнями самоопределения (myself) наций, общностей и индивидов, обусловливают проблемы гармоничного сосуществования различных локальных цивилизаций, что становится более очевидным на современном этапе развития глобального управления.

В контексте таких противоречий в статье представлены условия, в которых находится Республика Армения, стремящаяся интегрироваться в систему, в которой действуют про- 
цессы глобального управления. В то же время выявлена необходимость изучения проблемы культурного сотрудничества в условиях развития глобального управления, что предполагает сотрудничество цивилизаций, обусловленное необходимостью эволюционной модернизации национальной идентичности.

С этой целью рассматриваются такие вопросы, как «Кто наши соседи?», «Куда идет мир?» и "Можем ли мы измениться во имя нашего будущего?». Принимая во внимание то обстоятельство, что для отношений исламского мира и Запада характерны взаимное отрицание и столкновения, считаем, что с учетом национальных интересов Республики Армения нецелесообразно рассматривать политический ислам как источник терроризма.

Необходимо ясно осознавать, что, несмотря на определенную изоляцию, ислам благодаря гибкой и богатой системе ценностей смог не только модернизироваться и ответить на вызовы истории или сам бросить вызов, но также сорормировать концепцию диалога цивилизаций, предлагая ее в качестве альтернативного решения проблем, вставших перед человечеством [1].

С этой точки зрения интерес к ценностной системе ислама возрос, особенно после событий 11 сентября 2001 г. Многочисленные политические деятели, исследователи и эксперты развитых и развивающихся стран обратили свой взор в сторону мусульманского мира, рассматривая ислам в контексте нового миропорядка и проводя параллели между исламом и терроризмом, исламом и демократией, исламом и христианством. СМИ и Интернет последовательно обсуждают материалы с названиями «Священная война доходит до Америки», «Ислам в окружении», «Новый восход ислама, новая всемирная кампания против светского государства», «Джихад в Америке», «Ценности ислама и человечество».

Обобщая такие концепции, как конец истории [2], столкновение цивилизаций [3], рациональная оценка действительности [4], разложение евразийского ядра [5], американский политолог Э. Тод, изучающий процессы формирования нового миропорядка, пришел к выводу, что «целью истории является модернизация ценностной системы религии, которая сопровождается распространением либерально-демократических ценностей» $[6$, с. 9].

Целенаправленное изучение роли ислама осуществлено на основе сравнительного анализа таких концепций, как столкновение цивилизаций и сотрудничество цивилизаций, при этом сделан акцент на важности развития сотрудничества цивилизаций для эффективного управления полиэтническими пространствами (например, Российская Федерация, Южный Кавказ).

В данном контексте с точки зрения исследования современных проблем глобального управления концепция сотрудничества цивилизаций формирует необходимую ценностную основу для сосуществования (modus vivendi) религий с целью поиска ответа на стоящие перед человечеством вызовы. Так, в развитых странах представители «самоопределившихся сообществ», с одной стороны, эмоционально реагируя на политическую действительность, зачастую устраивают этнические чистки, провоцируют приграничные конфлликы, совершают политические теракты, а с другой стороны, остаются «пассивными» мусульманами.

В данном контексте интересен пример США, когда в 1965 г. благодаря либеральному закону о миграции мусульманская диаспора значительно пополнилась членами с ярко выраженным национальным самосознанием, хорошо знающими свою культуру, историю и религию. Последние, прибывшие в США с целью работы и учебы из Пакистана, Индии, Бангладеш, Турции, Ирана и т. д., не только активизировали созданную в 1931 г. организацию «Нация ислама» (Nation of Islam), но и основали другие. С этой точки зрения примечательны такие организации, как «Союз студентов-мусульман США и Канады» и “Совет мечетей» со своими 300 и 100 филиалами соответственно.

Согласно данным Центра церковных исследований народа и СМИ, около $10 \%$ от 10 млн мусульман США (6 млн белых и 4 млн черных) имеют низкий уровень жизни, 52 \% - средний, а 28 \% могут считаться богатыми ${ }^{1}$. Исходя из взаимосвязанности Востока и Запада, ислам может стать носителем сотрудничества цивилизаций. Более того, необходимо развивать не только диалог цивилизаций, но и сотрудничество цивилизаций, основанное на религиозной идентичности и ценностной многогранности, используя последнее в качестве фундамента нового миропорядка. В результате мы получим не столкновение цивилизаций, а конвергенцию идентичностей с различными религиозными основами в целях решения стоящих перед человечеством глобальных проблем.

${ }^{1}$ Pew Research Center for the People and the Press. URL: http: //people-press.org. 


\section{Осмысление понятия «глобальное управление»}

Глобальное управление - это относительно новое в международных отношениях явление, возникновение которого датируется серединой 1970-х гг. и связано с осознанием значения новых проблем, встающих перед человечеством. Процессы глобализации того политического времени диктовали необходимость существенно более высокой степени координации внутренней и внешней политики государств отдельно как в западном и восточном блоках, так и между двумя блоками.

Так, в книге «Глобальное управление: возможности и риски» отмечается, что «за последующие полвека глобальное управление претерпело значительную эволюцию во всех его аспектах - по его участникам, целям, идеологии, диапазону и содержанию решаемых задач, а также по его институтам. В то же время система глобального управления далека от завершенности, а мировое развитие 2000-х - начала 2010-х гг. поставило перед ней новые, существенно более сложные задачи». Вместе с этим подчеркивается, что «анализ политической и идеологической эволюции идеи и практики глобального управления позволяет точнее понять тенденции развития этого явления и тех задач, перед которыми оно стоит на перспективу 2010-2020-х гг.» [7, с. 10].

В данном ключе рассуждает и российский политолог М. М. Лебедева, которая отмечает, что «к концу $\mathrm{XX}$ столетия появилось новое понятие - глобальное управление (global govemance). В широкий оборот оно было введено В. Брандтом и его коллегами из Комиссии ООН по глобальному управлению (Commission on Global Governance). Kомиссия была создана для обсуждения того, как можно совместными усилиями решить такие глобальные проблемы, как экология, борьба с бедностью, болезнями и т. п. Окончание холодной войны также поставило вопрос о выработке новых правил поведения на мировой арене. Как результат, проблема глобального управления становится популярной в 1990-е годы. Выходят журналы Global Governance, Global Society. Данная тематика оказывается центральной и во многих других изданиях» $[8$, с. 331].

М. М. Лебедева приводит следующие подходы к пониманию того, что представляет собойглобальное управление. Первый подход фрактически повторяет то, что звучало задолго до окончания холодной войны, - идею формирования единого мирового правительства.
Суть второго подхода -провести реформирование международных организаций, и прежде всего ООН, которая становится центральным звеном управления, а ее институты начинают выполнять роль своеобразных «министерств» и «ведомств». Третий подход связан с идеями однополярного мира и управления им Соединенными Штатами в качестве главного актора. Наконец, четвертый подход состоит в том, что глобальное управление исходит из идеи полицентричности мира и предполагает участие в управлении не только государств и межгосударственных образований, но и других акторов. Именно их включенность в глобальное управление составляет главное отличие данного подхода от предыдущих [8, с. 331-333].

Особый интерес представляет также подход к пониманию проблем глобального управления профрессора А. И. Соловьева. Так, он пишет, что «существенное влияние на смысловую интерпретацию понятий «глобальная власть» и «глобальное управление» оказывают и традиции в использовании этого термина. В частности, чисто исторически термин «глобальное управление» (global governance) вошел в научный лексикон как некий более поздний аналог понятий «исторические изменения» (historical change) и «направляемые изменения» (guided change). B этом плане смысловое содержание данного термина в основном унаследовало противопоставление революционным и национально-агрессивным способам выстраивания мировых процессов, сигнализируя о возможности мирового сообщества взять под контроль стихийные процессы. Эти смысловые очертания впоследствии позволили интерпретировать «глобальное управление» как процесс поддержания определенных норм и принципов международного сотрудничества при помощи соответствующих институтов, способ удержания мирополитических связей, мирового порядка от крупных конорликтов и дестабилизирующих событий» [9, с. 11].

Следует отметить, что ученые используют термин «управление» для описания взаимозависимых отношений при отсутствии доминирующей политической власти, в частности в международной системе. Управление включает институты, политику, нормы, процедуры и инициативы, посредством которых государства и их граждане стремятся привнести предсказуемость, стабильность и порядок в свои ответы на международные вызовы. Принимая во внимание важность глобального управления, мы признаем возрастающую необходимость более эфффективного управ- 
ления глобальными проблемами при увеличившейся взаимозависимости стран.

С этой точки зрения важен подход Комитета ООН по политике развития. В частности, им подчеркивается, что «эфрфективное глобальное управление не может быть обеспечено без эфрфективного международного сотрудничества. Помимо того, что международное сотрудничество является манифестацией международной солидарности, оно также означает продвижение общих интересов и ценностей с целью снижения тех уязвимых точек, которые являются продуктом взаимозависимости» ${ }^{2}$.

Развивают данный подход авторы статьи «Глобальное управление: настоящее и будущее», которые считают, что глобальное управление - это продукт неолиберального парадигмального сдвига в международных политических и экономических отношениях. По их мнению, доминирование капиталистических и рыночных механизмов над государственной властью создало пробелы в управлении, побудившие акторов из частного и гражданского секторов взять на себя ответственность, которая ранее была закреплена за государством. Сказанное усиливает расхождение взглядов относительно того, как определять концепцию глобального управления. Авторы также говорят о том, что одни ученые полагают, что глобальное управление в сегодняшнем виде не работает, а другие верят, что оно постоянно адаптируется благодаря трансформации стратегий и подходов к решениям и выработке новых инструментов и механизмов для того, чтобы регулировать вопросы, которые влияют на сообщества по всему миру [10].

Таким образом, мы видим, что понятие «глобальное управление» является многогранной величиной, не поддающейся общему определению и включающей в себя различные как положительные, так и отрицательные компоненты. В данной работе мы исходим из понимания глобального управления как процесса, определяемого совокупностью непрерывных политических, экономических и других институциональных и неинституциональных действий государственных и негосударственных акторов, которые формируют и реализуют повестку международных отношений в конкретном политическом времени и пространстве.

${ }^{2}$ Global governance and global rules for development in the post-2015 era / Committee for Development Policy. URL: https://www.un.org/development/desa/dpad/ wpcontent/uploads / sites /45/publication / 2014-cdppolicy.pdf.

\section{Ценностная многогранность политического ислама}

Осмысление проблем глобального управления позволяет констатировать активное присутствие политического ислама в формировании современной повестки глобального управления.

С этой точки зрения представляется необходимым осмысление понятия «политический ислам». Сегодня в научной литературе существуют различные подходы к его пониманию. Так, российский политолог-исламовед Р. Н. Мухаметов считает, что «исламская политическая доктрина - это учение, научно-философрская теория, система, руководящий политический принцип, в основу которого положены аяты Корана, хадисы и выводы исламских богословов и мыслителей. Та или иная же исламская политическая идеология позволяет верующему с позиций исламской политической доктрины понять и оценить действительность, сорормулировать интересы и попытаться их реализовать. А выведенная на основе идеологии концепция определяет способ понимания, трактовки какого-либо явления» $[11$, с. 164].

Примечательно то, полагает Р. Н. Мухаметов, что в центре исламской политической доктрины лежит представление о том, что Коран и хадисы, а также выводимый из них иджтихад содержат все необходимые положения, на основе которых должна быть организована жизнь общества. «Согласно исламу, верховная власть, в том числе политическая, на Земле принадлежит Богу. Люди же призваны реализовывать ее. Исламу изначально и имманентно присуще политическое измерение. Очевидно, что расхожее клише «политизация ислама» является в научном отношении, мягко говоря, неуместным, ибо употребление его совершенно не учитывает семантики арабского термина «дин», который обычно передают на русский как «религия», а он этимологически включает в себя, помимо прочего, такие смыслы, как «подчинение», «власть», «закон» [там же, с. 164].

Наряду с этим специалист по внешней политике Ирана Хасан Джаббари Насир пишет, что «до XIX в. в исламских обществах был распространен традиционный ислам, который в силу относительной закрытости мусульманских обществ и ограниченности взаимодействий с внешним миром не присутствовал на политической арене. Однако постепенно он выходит на политическую сцену и начинает претендовать на более активное присутствие в разных социальных сферах общества, что было связано с растущим уров- 
нем столкновения с Западом, проблемами, вызванными отсталостью общества и колонизацией, а также существованием в исламских странах диктаторских правительств. С начала XX в. в результате прогресса средств коммуникации (печатные издания, телеграф, затем телефон, телевидение) и роста осведомленности народов о своей идентичности в некоторых странах ислам развился в своеобразную политическую культуру. В итоге сформировалась новая радикальная идентичность, которая критиковала, а в некоторых случаях даже отвергала существовавшие нормы традиционного ислама» [12].

В этой связи немецкий политолог и профессор международных отношений Бассам Тиби считает, что рост политического ислама и те неопределенности, которые он вызывает, связаны с так называемым френоменом «возвращения сакрального»: «Не более чем выражение ренессанса религии, это движение служит артикуляцией «восстания» против западных ценностей, выраженного в религиозной форме. В этом процессе политизации религии в исламской цивилизации исламисты раскрывают новую антизападную идеологию, порождая новую холодную войну с остальным миром в широком смысле» $[13$, c. 45].

Он говорит о том, что не хочет ни односторонне защищать «секуляризм» от религии, ни представлять «возвращение сакрального» в упрощенном виде. «Задача заключается в том, чтобы развивать «возвращение сакрального» для лучшего будущего, будущего без столкновения цивилизаций» [там же].

Особый интерес представляет также работа «Ислам в мировой политике в начале XXI века», в которой обосновывается идея о том, что под исламизмом, как правило, понимают политический ислам, а конечная цель исламских движений - социально-экономическое и политическое развитие государства и общества в соответствии с Кораном и исламскими традициями [14, с. 253].

Данный подход отражен также в работе фрранцузского политолога-востоковеда Оливера Роя, который считает, что термин «исламизм» (и его более мягкий эквивалент «политический ислам») попал в широкое употребление после Иранской революции 1979 г. и вскоре стал постоянным компонентом современного политического дискурса. По его словам, политологи стремились описать новый френомен - политические движения, возглавляемые образованными мусульманскими мирянами, которые защищали «реисламизацию» стран с большинством мусульманского населения (и мусульманских общин где бы то ни было) - всех тех, кто в их глазах перестал быть достаточно приверженным исламу. Эти движения продвигали шариат посредством современных форм общественной мобилизации, например путем создания филиалов специально для молодежи, женщин, рабочих. Организационная структура таких движений гибридная - сочетает традиционное суфистское братство (где члены проходят различные этапы посвящения) с формой современных политических партий, где консультативный совет назначает лидера, который регулирует работу технических комитетов в конкретных сорерах деятельности. О. Рой считает, что исламисты работали по двум направлениям - стимулирование социальных движений, которые должны сотрудничать с общинными и благотворительными организациями, а также формирование политического движения, которое будет бороться на выборах с целью продвижения своих членов в государственную бюрократию [15, с. 127-132].

Таким образом, можно прийти к выводу, что многогранность в понимании политического ислама обусловлена нелинейным характером процессов политической модернизации. Как следствие, можно утверждать, что в современных условиях политический ислам является одним из ключевых фракторов, влияющих на модернизацию процессов глобального управления, его гуманизацию и развитие предложенной нами концепции сотрудничества цивилизаций.

\section{Проект «Большой Ближний Восток» в контексте современных проблем глобального управления}

Политический ислам стал одним из основных столпов современных тенденций развития процесса глобального управления и нашел доминантное отражение в проекте «Большой Ближний Восток».

Теракты 11 сентября 2001 г. привели к активизации США на Ближнем Востоке. Уже в 2003 г. администрация Дж. Буша представила проект «Большой Ближний Восток» (ББВ) (Greater Middle East Initiative), направленный на усиление геополитических позиций США в этом регионе. Согласно проекту, ББВ включает арабский мир, Турцию, Израиль, Иран, Афганистан и Пакистан ${ }^{3}$. Однако, по мнению некоторых исследователей, проект

${ }^{3}$ U.S. Working Paper For G-8 / Sherpas / / Al-Hayat. 2004. Febr. 2. 
обращается ко всем проблемам и возможностям, которые существуют на территории, простирающейся от Марокко на западе до Индии на востоке, от Турции и Кавказа на севере до Судана и большой пустыни Сахара на юге, конечной целью проекта является разработка комплексной стратегии действий по отношению ко всему региону [16, с. 119].

Проект предусматривал установление демократической формы правления во всем исламском мире [17, с. 12]. С этой целью для публичного обсуждения он был представлен на саммите «Большой восьмерки», а затем опубликован в газете «Аль-Хаят» в фреврале 2004 г. Документ под названием «Американский рабочий документ для «Большой восьмерки» (U.S. Working) был подготовлен высокопоставленными чиновниками на саммите «Большой восьмерки» ${ }^{4}$. Говоря ○ проблемах ББВ, Роберт Харкави пишет, что «регион большей частью характеризуется отсутствием демократии, внутренней и эндемической нестабильностью и т. д.» $[18$, с. 43]. В документе определяется комплексная программа реформ, направленная на решение указанных проблем, состоящая из трех основных пунктов, каждый из которых представляет собой сложную систему мер: продвижение демократии и принципов «хорошего управления»; строительство общества знаний; расширение экономических возможностей. Продвижение демократии и принципов «хорошего управления» предполагается посредством следующих мер: проведение свободных выборов; парламентский обмен и тренинги; обеспечение свободы прессы; обеспечение прозрачности и борьба с коррупцией; развитие гражданского общества. Строительство общества знаний должно происходить через продвижение базового образования, в частности развитие грамотности среди населения, проведение образовательной реформы, а также осуществление таких инициатив, как распространение цифровых знаний и бизнес-образования. И третий компонент программы - расширение экономических возможностей - включает проведение форума «Экономические возможности Большого Ближнего Востока», а также инициативу «Финансы для развития». Последнее подразумевает микрокредитование, финансирование корпораций, создание Банка развития Большого Ближнего Востока (GMEDBank), способствование вхождению стран региона в ВТО и содействие торговле, создание торговых связок, а также зон биз-

${ }^{4}$ U.S. Working Paper For G-8. нес-инкубаторов ${ }^{5}$. Таким образом, данный проект предполагает комплекс мер, направленных на распространение собственной идентичности и установление собственной гегемонии в регионе путем крупномасштабного реформирования государственного управления, обеспечения политической свободы и развития гражданского общества. Эти интеграционные процессы должны стимулировать развитие как региона в целом, так и каждой отдельной страны. С другой стороны, этот процесс должен привести к формированию проамериканских треков на всех трех уровнях (элита/гражданское общество, народ и личность).

Однако реализация данной задачи имеет множество недостатков, одним из которых является отсутствие харизматичных лидеров, характерных для революционного движения. В этом смысле интересно замечание Г. Почепцова, который пишет: «...в результате есть майдан, есть смыслы, но нет лидера. Лидера не только должны видеть все, но и он должен видеть дальше всех. Только так к нему возникнет доверие» [19]. Г. Почепцов излагает свои взгляды в отношении украинского майдана, однако ситуация трафраретна и для стран ББВ. Именно отсутствие такого лидера порождает тот хаос, который мы наблюдаем практически во всех странах, где происходила «арабская весна». В контексте рассмотрения проблем ББВ важным и интересным представляется изучение его геополитического и геостратегического значения, которое не может не ставить регион в центр международной политики сегодня. Так, здесь сосредоточены одни из самых богатых в мире месторождений энергоносителей. В частности, три четверти всех ресурсов нефти расположены в 13 странах ББВ ${ }^{6}$.

\section{Политический ислам и проблема прав человека}

В условиях развития глобального управления с целью обеспечения стабильного развития необходимо изучить связь между демократией и политическим исламом, а также понять, противоречат ли друг другу эти два понятия. В рамках как академических, так и практических исследований делаются полярные выводы. Так, исламский политолог Калим Сидикуин определяет демократию как одно из современных «политических неверий»: «Самое большое неверие (kufr) современного мира это национализм, за которым сразу следуют

${ }^{5}$ U.S. Working Paper For G-8.

${ }^{6}$ International Energy Outlook. Washington, 2003. P. 184-186. DOE/EIA-0484. 
демократия (суверенитет людей), социализм (диктатура пролетариата), капитализм и свобода воли. Все остальные политические системы, которые основаны на подобных идеях, являются частью «куфры» [20].

В то же время Э. Кедури, подчеркивая важность модернизации ислама, пишет: «Идея представительства, выборов, политических институтов, регулируемых законом, светского государства и другие идеи подобного рода полностью соответствуют мусульманским политическим традициям» [21, с. 5].

С этой точки зрения примечателен подход политолога А. С. Котанджяна относительно модернизации как цивилизационного явления: «Модернизация имеет важное значение в деле развития этнонациональных явлений, поскольку она коренным образом меняет условия функционирования нации или этнической группы» [22].

Рассматривая данный подход, необходимо отметить, что модернизация - это одно из средств развития истории мира, благодаря которому преодолевается традиционный быт средневековой цивилизации. Более того, модернизация с помощью различных традиций может обеспечить стабильное развитие человечества. Это именно то, что делает исламская модернизация с мусульманскими странами, где власть опирается на мощь военных, а также на развитые страны.

Активизированные в рамках «третьей волны» демократизации мусульманские народы начали требовать больше автономии, поскольку исламские деятели все больше пользуются демократическими ценностями, опираясь на мусульманские традиции. В последние годы подобного рода демократию принимает все больше мусульман, представляя специфические для ислама виды демократии или политического участия народа, ища и находя их в исламских традициях.

Такие традиционные понятия ислама, как политический дискурс или совещание (шура), консенсус общины (иджма) и индивидуальная интерпретация (иджтихад), переосмысливаются с целью обоснования понятий «парламентская демократия», «представительские выборы» и "рефрорма религии».

Такие исламские организации, как «Братья-мусульмане» в Египте и Иордании, «Джамаат-и-ислами» в Пакистане, Индии и Бангладеш, а также «Исламский фронт спасения» Алжира, Партия возрождения Туниса и др., поддержали принцип выборов «исламской демократии».

В отличие от западной модели демократии, которой свойствен неограниченный суверенитет народа, в «исламской демократии» суверенитет народа ограничен законами Аллаха и мазхабами - нормами школ шариатского права, которые создают уникальный баланс между ним и народом, развивая "демократию без риска», "демократию без инакомыслия» и «демократию Аллаха».

Однако в рамках подобной демократии существенными проблемами являются терпимость к плюрализму мнений и политическому инакомыслию, а также статус меньшинств и свобода слова в тех странах, где мусульмане составляют большинство. Опыт политической модернизации таких стран показывает, что процесс установления «исламской демократии» сопровождается игнорированием прав меньшинств (других конфессий, женщин, этнических групп). Для мусульман принцип плюрализма мнений тесно связан с предоставляемым по мусульманскому праву немусульманам статусом защищенных меньшинств, а также статусом мусульманских меньшинств в немусульманских странах.

В процессе развития глобального управления одной из важнейших проблем является совместимость традиционных моральных норм с современными принципами прав и свобод человека. В данном контексте исследователи в области ислама отмечают, что отдалившийся от христианских ценностей Запад путает права человека с принципом вседозволенности. С этой точки зрения в процессе развития ценностной базы глобального управления появились новые цивилизационные модели, которые, ставя под сомнение западную концепцию прав человека (в частности, Всеобщую декларацию прав человека, принятую Генеральной ассамблеей ООН в 1948 г.), предлагают альтернативные концепции прав человека. Так, Х Всемирным русским народным собором в апреле 2005 г. была принята Декларация о правах и достоинстве человека.

Подобная позиция существует и в исламском мире, который выдвинул собственную концепцию прав и свобод человека. Последняя была закреплена в Каирской декларации о правах человека в исламе, принятой в ходе состоявшейся 5 августа 1990 г. в Египте встречи глав МИД стран, входящих в Организацию исламского сотрудничества7.

${ }^{7}$ Cairo Declaration on Human Rights in Islam : adopted and Issued at the Nineteenth Islamic conference of Foreign Ministers in Cairo on 5 August 1990. URL: http://www. fmreview.org/sites/fmr/files/FMRdownloads/en / FMRpdfs/Human-Rights/cairo.pdf. 
Декларация, суммировав ценностную базу ислама, подчеркивает, что с точки зрения человеческого достоинства, обязанностей и ответственности все люди равны и не должны подвергаться дискриминации по расовому, половому, религиозному, политическому, социальному, языковому и другим признакам (ст. 1, п. «а»). Все люди являются слугами бога, и никто не должен иметь превосходство над другими (ст. 1, п. «б»).

Каирская декларация прав человека придает важное значение семье как важнейшему общественному институту, заключать узы брака друг с другом имеют право мужчина и женщина, для чего не существует расовых или национальных ограничений (ст. 5, п. «а»).

Согласно Каирской декларации прав человека, человек должен руководствоваться основополагающими нормами ислама. Данная концепция не считает правильным ставить в центр глобального управления личность и восхвалять ее, потому что мир является сообществоцентричным, в то время как в западной концепции именно человек является началом и собственником всего, поскольку человекоцентричность позволяет быть приверженным ценностной многогранности, устанавливая возможную инорормационно-коммуникационную действительность. Это значит, что человек сам решает, что ему делать и, пренебрегая историческим опытом, на основании оценки действительности выбирает между хорошим и плохим, добром и злом, возможным и невозможным.
Западное понимание прав человека не ограничивает возможности человека, в результате чего формируется гедонистическая, эмоциональная и материальная культура Запада. Примечательно, что в Каирской декларации большое место уделено исламу в триединстве прошлое - настоящее - будущее, а установление демократических ценностей в исламских государствах рассматривается как единственный способ спасения от экологических катастроф, нежелательных революций и различных войн.

\section{Заключение}

Политический ислам стал неотъемлемой частью политической мысли и формы деятельности современного этапа развития глобального управления. Он является специфической лакмусовой бумагой, с помощью которой проверяется, с одной стороны, толерантность властей, а с другой - способность мусульманских ценностей к модернизации. Наряду с этим развитие политического ислама предполагает реализацию политики сотрудничества цивилизаций. Логика мультикультурной сущности современного глобального управления, а также ее неопределенность и конфрликтный потенциал обосновывают необходимость развития сотрудничества цивилизаций как ключевого фактора мирного и гармоничного сосуществования полиэтнических государств с целью сохранения и развития этнонациональной идентичности каждого уникального сообщества людей.

\section{СПИСОК ИСПОЛЬЗОВАННОЙ ЛИТЕРАТУРЫ}

1. Ислам и политика (взаимодействие ислама и политики в странах Ближнего и Среднего Востока, на Кавказе и в Центральной Азии) / отв. ред. В. Я. Белокреницкий. - М. : Ин-т востоковедения РАН, 2001. - 420 с.

2. Фукуяма Ф. Конец истории и последний человек / Ф. Фукуяма. - М. : АСТ, 2004. - 588 с.

3. Хантингтон С. Столкновение цивилизаций / С. Хантингтон. - М. : АСТ, 2003. - 603 с.

4. Киссинджер Г. Нужна ли Америке внешняя политика? / Г. Киссинджер. - М. : Ладомир, 2002. - 352 с.

5. Бжезинский 3. Великая шахматная доска (Господство Америки и его геостратегические императивы) / 3. Бжезинский. - М. : Междунар. отношения, 1999. - 216 с.

6. Todd E. After the Empire: The Breakdowns of the American Order / E. Todd. - New York : Columbia Univ. Press, 2003. $-233 \mathrm{p}$.

7. Глобальное управление: возможности и риски / отв. ред. В. Г. Барановский, Н. И. Иванова. - М. : ИМЭМО РАН, 2015. - $315 \mathrm{c}$.

8. Лебедева М. М. Мировая политика : учебник / М. М. Лебедева. - 2-е изд., испр. и доп. - М. : Аспект Пресс, 2007. - 365 c.

9. Глобальное управление : учеб. пособие / под ред. А. И. Соловьева. - М. : Инфра-М, 2007. - 252 с.

10. Jang J. Global governance: present and future [Electronic resource] / J. Jang, J. McSparren, Y. Rashchupkina / / Palgrave Communications. - 2016. — Jan. 19. - Mode of access: https: / /www.nature.com/ articles/palcomms201545.pdf.

11. Мухаметов Р. М. Политическое самоопределение исламского мира в условиях глобализации (политические доктрины и действия) / Р. М. Мухаметов. - М. : Медина, 2008. - 164 с.

12. Хасан Джаббари Насир. Политический ислам, терроризм и безопасность на Ближнем Востоке / Хасан Джаббари Насир / / Вестник МГИМО-Университета. — 2017. - № 5 (56). - С. 183-198.

13. Bassam Tibi. Political Islam, world politics, and Europe / Bassam Tibi. — New York : Routledge, 2008. - 328 p.

14. Ислам в мировой политике в начале XXI века / под ред. Л. М. Ефимовой, М. А. Сапроновой. - М. : МГИМО-Университет, 2016. - 345 с.

15. Roy O. Political Islam After the Arab Spring: Between Jihad and Democracy / O. Roy / / Foreign Affairs. 2017. - Vol. 96, iss. 6. - P. 127-132. 
16. Hatipoglu E. The European union`s role in the Greater Middle East [Electronic resource] / E. Hatipoglu. Mode of access: http: / / www.fscpo.unict.it/EuroMed/EDRC5/euusamed01.pdf.

17. Osman Nuri Özalp. Where is the Middle East? The Definition and Classification Problem of the Middle East as a Regional Subsystem in International Relations / Osman Nuri zalp / / Turkish Journal of Politics. — 2011. — Vol. 2, № 2. - P. 5-21.

18. Harkavy R. Strategic Geography and the Greater Middle East / R. Harkavy // Naval War College Review. - 2001. — № 4 .

19. Почепцов Г. Информационно-коммуникативные технологии в развитии цивилизации [Электронный ресурс] / Г. Почепцов. - Режим доступа: http://www.ji-magazine.Iviv.ua/anons2014/Pochepcov_Informkomunikatyvn_technolog.htm.

20. Siddiqui K. Primary Goals and Achievements of the Islamic Revolution in Iran [Electronic resource] / K. Siddiqui. - Mode of access: https://www.icit-digital.org/articles/primary-goals-and-achievements-of-theislamic-revolution-in-iran.

21. Kedourie E. Democracy and Arab Political Culture. Washington [Electronic resource] / E. Kedourie. Washington, 1992. - Mode of access: https://www.washingtoninstitute.org/uploads/Documents/pubs/Democ racyandArabPoliticalCulture.pdf.pdf.

22. Котанджян Г. С. Политологические проблемы безопасности: Перестройка СССР - Карабах, Армения, Закавказье - Афрганистан / Г. С. Котанджян. - Ереван, 2009. - 656 с.

\section{REFERENCES}

1. Belokrenitskii V. Ya. Islam i politika (vzaimodeistvie islama i politiki v stranakh Blizhnego i Srednego Vostoka, na Kavkaze iv Tsentralnoi Azii) [Islam and Politics (Interaction between Islam and Politics in the Countries of the Middle East, Caucasus and Central Asia)]. Moscow, Institute of Oriental Studies of Russian Academy of Sciences Publ., 2001. 420 p.

2. Fukuyama F. The end of history and the last man. New York, 1992. 418 p. (Russ. ed.: Fukuyama F. Konets istorii i poslednii chelovek. Moscow, AST Publ., 2004. 588 p.).

3. Huntington S. P. The clash of civilizations and the remaking of world order. New York, 1996. (Russ. ed.: Huntington S. P. Stolknovenie tsivilizatsii. Moscow, AST Publ., 2003. 603 p.).

4. Kissinger H. Does America Need a Foreign Policy? New York, Harper, 1957. (Russ. ed.: Kissinger H. Nuzhna li Amerike vneshnyaya politika? Moscow, Ladomir Publ., 2002. 352 p.).

5. Brzezinski Z. The Grand Chessboard: American Primacy and Its Geostrategic Imperatives. New York, 1997. (Russ. ed.: Brzezinski Z. Velikaya shakhmatnaya doska (Gospodstvo Ameriki i ego geostrategicheskie imperativy). Moscow, Mezhdunarodnye otnosheniya Publ., 1999. 216 p.).

6. Todd E. After the Empire: The Breakdowns of the American Order. New York, Columbia University Press, 2003. $233 p$.

7. Baranovskii V. G., Ivanova N. I. (eds.). Globalnoe upravlenie: vozmozhnosti i riski [Global Governance: Opportunities and Risks]. Moscow, Institute of World Economy and International Relations of Russian Academy of Sciences Publ., 2015. 315 p.

8. Lebedeva M. M. Mirovaya politika [Global Policy]. $2^{\text {nd }}$ ed. Moscow, Aspekt Press Publ., 2007. 365 p.

9. Solovev A. I. Globalnoe upravlenie [Global Governance]. Moscow, Infra-M Publ., 2007. 252 p.

10. Jang J., McSparren J., Rashchupkina Y. Global governance: present and future. Palgrave Communications, 2016, January 19. Available at: https://www.nature.com/articles/palcomms201545.pdf.

11. Mukhametov R. M. Politicheskoe samoopredelenie islamskogo mira v usloviyakh globalizatsii (politicheskie doktriny i deistviya) [Political Self-Identification of Islamic World in the Context of Globalization (Policy Doctrines and Actions)]. Moscow, Medina Publ., 2008. 164 p.

12. Hasan Jabbari Nasir. Political Islam, Terrorism and security in the Middle East. Vestnik MGIMO-Universiteta = Vestnik MGIMO-University, 2017, no. 5 (56), pp. 183-198. (In Russian).

13. Bassam Tibi. Political Islam, world politics, and Europe. New York, Routledge, 2008. $328 \mathrm{p}$

14. Efimova I. M., Sapronova M. A. Islam v mirovoi politike $v$ nachale XXI veka [Islam in the Global Politics at the beginning of the $21^{\text {st }}$ Century]. Moscow, MGIMO-Universitet Publ., 2016. 345 p.

15. Roy O. Political Islam After the Arab Spring: Between Jihad and Democracy. Foreign Affairs, 2017, vol. 96, iss. 6, pp. 127-132.

16. Hatipoglu E. The European Union's role in the Greater Middle East. Available at: http: / /www.fscpo.unict. it/EuroMed/EDRC5/euusamed01.pdf.

17. Osman Nuri Özalp. Where is the Middle East? The Definition and Classification Problem of the Middle East as a Regional Subsystem in International Relations. Turkish Journal of Politics, 2011, vol. 2, no. 2, pp. 5-21.

18. Harkavy R. Strategic Geography and the Greater Middle East. Naval War College Review, 2001, no. 4.

19. Pocheptsov G. Informatsionno-kommunikativnye tekhnologii $v$ razvitii tsivilizatsii [Informational and Communicative Technologies in Civilization Development]. Available at: http://www.ji-magazine.Iviv.ua/ anons2014/Pochepcov Inform-komunikatyvn technolog.htm. (In Russian).

20. Siddiqui K. Primary Goals and Achievements of the Islamic Revolution in Iran. Available at: https://www. icit-digital.org/articles/primary-goals-and-achievements-of-the-islamic-revolution-in-iran.

21. Kedourie E. Democracy and Arab Political Culture. Washington, 1992. Available at: https://www. washingtoninstitute.org/uploads/Documents/pubs/DemocracyandArabPoliticalCulture.pdf.pdf.

22. Kotandzhyan G. S. Politologicheskie problemy bezopasnosti: perestroika SSSR - Karabakh, Armeniya, Zakavkaze - Afganistan [Politological Issues of Security: Perestroika of the USSR - Karabagh, Armenia, the Caucasus Region - Afghanistan]. Erevan, 2009.656 p. 


\section{Информация об авторе}

Маргарян Мамикон Гарегинович - кандидат политических наук, кафедра политического управления и публичной политики, Академия государственного управления Республики Армения, главный специалист-эксперт фрракции Республиканской партии Армении (РПА) Национального Собрания Республики Армения, Ереван, Республика Армения, e-mail: margaryan.mamikon@gmail.com.

\section{Для цитирования}

Маргарян М. Г. Политический ислам и современные проблемы глобального управления / М. Г. Маргарян // Известия Байкальского государственного университета. - 2018. - Т. 28, № 2. - C. 230-239. - DOI: 10.17150/25002759.2018.28(2).230-239

\section{Author}

Mamikon G. Margaryan - Ph.D. in Political Science, Chair of Political Governance and Public Policy, Public Administration Academy of the Republic of Armenia, Leading specialist of the Republic Party of Armenia (RPA) fraction of the National Assembly of the RA, Yerevan, Republic of Armenia, e-mail: margaryan. mamikon@gmail.com.

\section{For citation}

Margaryan M. G. Political Islam and the Modern Issues of Global Governance. Izvestiya Baykal'skogo gosudarstvennogo universiteta $=$ Bulletin of Baikal State University, 2018, vol. 28, no. 2, pp. 230-239. DOl: 10.17150/2500-2759.2018.28(2).230-239. (In Russian). 